\title{
Engaged scholarship on the High Street: the case of HSUK2020
}

\author{
Nikos Ntounis \\ Institute of Place Management, Manchester Metropolitan University Business \\ School, Manchester Metropolitan University, Manchester, UK, and \\ Cathy Parker \\ Institute of Place Management, Business School, \\ Manchester Metropolitan University, Manchester, UK
}

\begin{abstract}
Purpose - The purpose of this paper is to introduce engaged scholarship as a method for addressing the "wicked problem" of High Street change through successful collaboration and co-production of knowledge between academics, practitioners, citizens and other place stakeholders.

Design/methodology/approach - The first part of this paper introduces engaged scholarship as a participatory form of research and situates it within the context of the High Street. The second part presents the case of High Street UK 2020 (HSUK2020) via Van de Ven's diamond model of engaged scholarship as a guide.

Findings - Engaged scholarship's focus on knowledge production and on collaboration between the research team and the community enabled us to improve the understanding of factors affecting High Streets amongst a diverse group of stakeholders and focus on what works for the towns. The ongoing impact of HSUK2020 on the project towns' action plans and on this current research is testament to how engaged scholarship research can drive the agendas for both academics and communities.

Originality/value - The paper presents engaged scholarship as an alternative collaborative method of conducting research on the High Street, one that is more in line with the current trends in retailing and works as a motivating factor for community engagement.
\end{abstract}

Keywords High Street, Co-production, Knowledge exchange, Collaborative research, Engaged scholarship

Paper type Research paper

The High Street is widely established as a dynamic construct with a multitude of stakeholders and a plethora of factors that contribute to an "endless litany of change" (Morganosky, 1997, p. 269). The complexities of dealing with the High Street have been well documented in the literature (Clarke et al., 1997; Hernandez et al., 1998; Peel, 2010; Pioch and Byrom, 2004; Wrigley and Dolega, 2011; Wrigley and Lambiri, 2014), and these complexities can constrain the attempts of local authorities, retailers, citizens and other key stakeholders to plan and adapt effectively. This is an enduring situation in most places, and the abundance of academic research, market reports, High Street data, as well as the extensive interest from the media and the public, seem to have had little effect on the ground (Parker

(C) Nikos Ntounis and Cathy Parker. Published by Emerald Publishing Limited. This article is published under the Creative Commons Attribution (CC BY 4.0) licence. Anyone may reproduce, distribute, translate and create derivative works of this article (for both commercial and noncommercial purposes), subject to full attribution to the original publication and authors. The full terms of this licence may be seen at http://creativecommons.org/licences/by/4.0/legalcode 
JPMD

10,4

et al., 2016, p. 3). The ongoing decline in the importance of the High Street, which impacts upon both retailers and communities, has thereby not yet been alleviated.

These challenges have led to our understanding of the High Street as a "wicked problem", which requires successful collaboration between place stakeholders, researchers and practitioners to tackle the misalignments between academic and practitioner knowledge. "Wicked problems" call for participatory approaches to research that can "enable the mutually beneficial reciprocal-exchange of resources and knowledge" between the relevant parties (Phillips et al., 2013, p. 235). In this article, we present such an approach, which was influenced by the tenets of engaged scholarship (Van de Ven, 2007) and guided the ESRC-funded High Street UK 2020 project. By situating engaged scholarship in the context of retailing and the High Street, we argue that such an approach can address the issues of the limited application of existing academic knowledge to the problem, as well as develop and exchange new knowledge of relevance and rigour for High Street stakeholders, researchers and practitioners (Pettigrew, 2001). Furthermore, we present how our collaborative relationship with place stakeholders helped us to provide useful models of High Street performance that represent a more commonly held "reality" (Rescher, 2003), can be easily interpreted and therefore be put into practice more easily (through, for example, towns' development or action plans). Based on our High Street UK 2020 project, we demonstrate how engaged scholarship, as a form of research that requires "researchers and practitioners (to) coproduce knowledge that can advance theory and practice in a given domain" (Van de Ven and Johnson, 2006, p. 803), can provide an alternative to dominant methodological approaches in the fields of retailing, town centre management and place management.

\section{What is engaged scholarship?}

In academia, and particularly in business schools, finding ways to address the theorypractice gap and harmonise the scholarly pursuits of researchers with society's pressing concerns is a recurring issue (Phillips et al., 2013). As King and Learmonth (2015) illustrate, the relevance, usefulness, applicability and impact of original academic research has been questioned repeatedly (Boyer, 1996; Learmonth et al., 2012; Shapiro et al., 2007; Smith et al., 2011; Starkey and Madan, 2001). This has led to the "growing realization that so-called 'theory' and 'practice' cannot be bifurcated as separate domains" (King and Learmonth, 2015, p. 354). What is required, therefore, is a shift in how researchers approach the knowledge production problem by moving from an "unengaged process of inquiry in social research" (Van de Ven, 2007, p. 5) to a research style that is participatory, reflexive, transdisciplinary, collaborative and directed towards accomplishing societal advancements while maintaining research quality (Cuthill, 2010; Gibbons et al., 1994).

Engaged scholarship is a participatory style of research for obtaining the understanding of a complex problem in its particular context (Van de Ven, 2007) and typically from those key stakeholders affected by the issue being studied. Its origins can be traced to the work of Boyer (1990), who argued that scholarly activities need to move beyond the conduct of original research (scholarship of discovery) to form a dynamic definition of scholarship that helps to build bridges between theory and practice (scholarship of integration); incorporates scientific discovery with problem-solving that assists individuals and communities (scholarship of application); and promotes educational progress (scholarship of teaching) (also see Paynter, 2014). The scholarship of engagement entails the deployment of the above activities from outside the campus to people and places, and the work of the engaged scholar can, in turn, be directed towards larger, more humane ends (Boyer, 1990). As Van de Ven (2007, p. 9) observes, 
such collaboration in knowledge production can result in "knowledge that is more penetrating and insightful than when scholars or practitioners work on the problems alone".

Subsequently, engaged scholarship advocates a fundamental shift in the relationship between researchers and other stakeholders (Van de Ven, 2011). This begins with a recognition that the problem under study cannot be answered with one person's limited resources and capabilities. This thus leads researchers to adopt a participant frame of reference and engage in a reflexive, collective learning process that respects all other kinds of knowledge production (Alvesson and Sköldberg, 2000; Hendrickx, 1999). Furthermore, engaged scholarship requires researchers to adopt a pluralist view of science and practice and participate in conversation and discourse with different people, with the goal to produce new but complementary knowledge outputs that can help answer complex problems (Van de Ven, 2007). Engaged scholarship can thus be understood as a collaborative research method that advances scientific knowledge, helps to understand complex real-life problems and has emancipatory potential (Huzzard and Johansson, 2014; Strumińska-Kutra, 2016). Therefore, engaged scholarship has strong bonds with critical management studies, collaborative inquiry and participatory action research. This is because it also advocates that academics be actively involved in practice and in the creation of practice-based knowing to achieve transformative goals in society (King and Learmonth, 2015; Willmott, 2008; Wolfram Cox et al., 2009).

This deviation from traditional, self-referential scholarship which fits the researcher's view and values is also reflected in the philosophical underpinnings of engaged scholarship, which favours a "more inclusive research philosophy that is open to and integrates some of the differences of alternative philosophies of science" (Van de Ven, 2007, p. 63). Hence, engaged scholarship adopts a realist position that includes elements from different philosophical approaches (e.g. critical realism, pragmatism, constructivism and critical theory) and allows researchers to better coordinate the multiple models, theories and perspectives that are constructed and identified during the research process (Azevedo, 1997). Engaged scholarship thus favours the use of multidimensional methods and theories and obtains findings by triangulation through engagement. As Van de Ven (2007, p. 285) asserts, such an approach:

[...] increases the richness (and complexity) of problem representation, and decreases the likelihood of myopic representations that other stakeholders may perceive as being biased and misdiagnosed views of the "real world" situation.

Although engaged scholarship attempts to connect different research approaches, which can lead to theoretical and methodological contradictions and inconsistencies (StrumińskaKutra, 2016), it enables an evolutionary growth of knowledge via the development of models that "better fit the problems they are intended to solve" (Van de Ven, 2007, p. 70). Thus, as Wells (2016, p. 43) describes, engaged scholarship does not attempt to seek generalisability but rather aims for relevant theorisation and explanation in a specific situation through an immersive, interactive and emergent collaborative learning process.

\section{Engaged scholarship in the context of the High Street}

When comparing the underlying assumptions of engaged scholarship with the High Street and its academic disciplines or areas (e.g. retailing, marketing, geography, planning and public administration), a degree of similarity is evident. High Street performance and development, which, in the UK, is often investigated under the labels of "town centre management" and "place management" has long been associated with different types of engagement which are integral in place decision-making, such as business engagement 
JPMD

10,4

(Coca-Stefaniak et al., 2005; Dawkins and Grail, 2007; Parker et al., 2014; Wrigley and Dolega, 2011), multiple stakeholder engagement (De Nisco et al., 2008; Omholt, 2013; Warnaby et al., 2005) and community engagement (Coca-Stefaniak and Carroll, 2015; Woolrych and Sixsmith, 2013). Engagement between established town partnerships (e.g. business improvement districts, local development companies, community interest companies, town teams and the local government) can "create more efficient, inclusive and pluralist local governance, bringing together key organizations and actors [...] to identify communities" top priorities and needs and work with local people to provide them (Geddes, 2006, p. 87).

Moreover, working in partnerships has long been recognised as an important objective in local community agendas as a way for addressing complex and interrelated issues, such as the future of the High Street, through trust-building and knowledge-sharing exercises (Balloch and Taylor, 2001; Raco, 2000; Taylor, 2006). In this sense, researchers' engagement within these partnerships is not only aligned with the tenets of engaged scholarship but also consistent with current policies regarding local governance in the UK (DCLG, 2009). Therefore, merging engaged scholarship into the already well-established processes of town centre and place management can be a step towards the strengthening of stakeholder participation in the management of the High Street and can also stimulate opportunities for learning, dialogue, and knowledge production for everyone involved (Peel, 2003).

Furthermore, when examining the literature concerning collaborative planning and strategic spatial planning, valuable outcomes that fit with engaged scholarship can be drawn regarding stakeholder/community interaction, conflict resolution and consensus building in a pluralistic environment (Brand and Gaffikin, 2007; Depriest-Hricko and Prytherch, 2013; Healey, 1998, 2006; Innes, 1996). Indeed, engaged scholarship can mesh well in participatory projects and town partnerships, where the multitude of understandings and the constant conflict of values and interests that are entailed in all stakeholder interactions need to be recognised and eventually legitimised (Albrechts, 2015; Hillier, 2003; Mouffe, 2005). Engaged scholarship's theoretical and methodological pluralism can be utilised to support what Brand and Gaffikin (2007) label as the "smart pluralism" approach, which shifts away from coercive dominance and aims to maximise the chance of positive outcomes via compromise and knowledge exchange (Le Feuvre et al., 2016). Strategising in pluralistic contexts raises various challenges (e.g. inflationary consensus, collective paralysis, inertia and the dilution of town initiatives) (Denis et al., 2007), reflecting criticisms regarding the ability of engaged scholarship to produce valuable results in the long term (McKelvey, 2006). However, the "splicing" of methodological, theoretical and "on the ground" pluralisms can be a vehicle towards the production of more insightful knowledge for academics and both emergent and intended strategies for town partnerships (Arkesteijn and Volker, 2013). In the next section, we demonstrate how our approach to engaged scholarship corresponded to the participatory processes that took place during the life of the High Street UK 2020 project.

\section{High Street UK 2020: a model of engaged scholarship}

To explain our approach to the High Street UK 2020 project, we will use Van de Ven's (2007) diamond model of engaged scholarship (Figure 1) as a guide for the milestones and outcomes that stemmed from our engagement with stakeholders. Van de Ven's model is appropriate for this purpose, as it is a knowledge production model that advises collaboration with stakeholders and the researchers at every stage of a research project, including problem formulation, theory building, research design and problem-solving (Hunt, 2008). It is also an iterative model, which allows us to illustrate how our method enabled "simultaneous problem solving of lower level issues within the greater research question at 


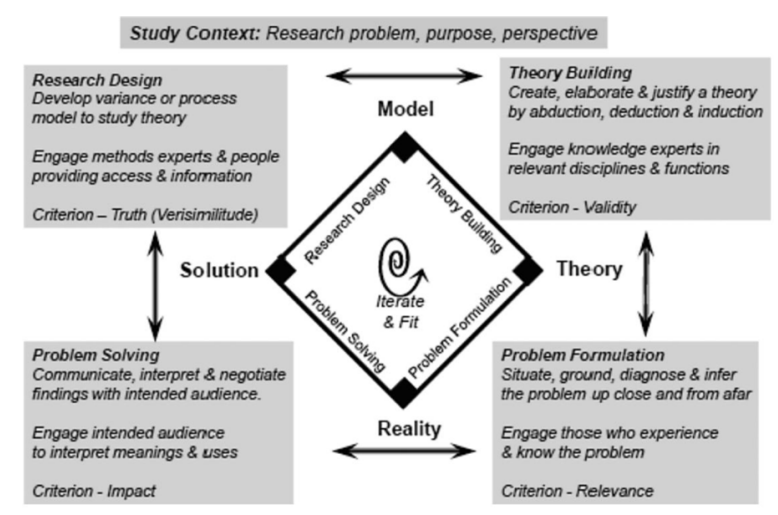

Source: Van de Ven (2007)

\section{Engaged scholarship on the High Street}

353

Figure 1.

Van de Ven's model of engaged scholarship

hand" (Phillips et al., 2013, p. 236). Our model of engaged scholarship differs slightly from Van de Ven's, as it takes numerous case studies and a plethora of stakeholders into the knowledge transfer/exchange loop (also see Wells, 2016). However, Van de Ven's model follows a step-by-step approach that enables us to frame the research in a simple and effective way. We will now present each stage of our research project more thoroughly, and an outline of the milestones and outcomes at every stage can be found in Table I.

\section{Problem formulation}

In the initial stage of the project, and prior to the production of the bid, we started to engage with key stakeholders (e.g. retailers, town centre partnerships, local authorities, property owners/developers and residents) to attain their views of the High Street knowledge problem. At this stage, the researchers adopted an approach akin to a journalist, by being open to the interpretations of others, able to answer the basic questions of why, when, what, where, who and how the problem exists and learning to appreciate the problem's multiple dimensions and manifestations (Van de Ven, 2007, pp. 77-79). What was clear from our discussions with stakeholders was the uncertainty of how to manage or develop a High Street that could meet the needs of its community, perhaps not immediately, but in the fairly near future (i.e. 2020 and beyond). From our initial collaboration, it was apparent that academic and professional knowledge was fragmented and that the study of retail change in particular geographic locations was limited (Wang, 2011), thus making it difficult to those experiencing the problem to secure the future of their town centres. With this in mind, we started developing a project bid that would help the local agents of change to identify and understand their information requirements, get access to accurate and relevant academic knowledge, to improve the quality of decision-making and provide a solid academic underpinning to their plans for action. The bid was developed as an ESRC knowledge exchange project for a large-scale retail sector initiative and addressed the following key project questions:

Q1. Why have High Street stakeholders not acted on the research and data that has been available to manage change in a more effective way?

Q2. How can research and data be delivered more effectively to High Street stakeholders so that it is used to inform decision-making? 
Research project: High Street UK 2020: Transferring knowledge to facilitate the repositioning, reinventing, rebranding and restructuring of sustainable retail centres

Research aim: To channel the existing academic knowledge relating to retail and High Street change directly to individual locations, as well as work directly with the end users of research to identify gaps for further investigation and research

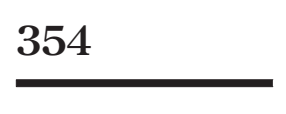

Stakeholders

\begin{tabular}{lll} 
Research stage involved Activities $\quad$ Outcomes \\
\hline
\end{tabular}

\begin{tabular}{|c|c|c|c|}
\hline $\begin{array}{l}\text { Problem } \\
\text { formulation }\end{array}$ & $\begin{array}{l}\text { High Street } \\
\text { stakeholders }\end{array}$ & $\begin{array}{l}\text { Discussions with key } \\
\text { stakeholders }\end{array}$ & $\begin{array}{l}\text { Grounding the problem in the context of } \\
\text { sustainable High Street } \\
\text { Production of research bid based on } \\
\text { stakeholders' perspectives }\end{array}$ \\
\hline Theory building & $\begin{array}{l}\text { Research team } \\
\text { Retail experts } \\
\text { Project partners }\end{array}$ & $\begin{array}{l}\text { Systematic literature } \\
\text { review } \\
\text { Initial theory of High } \\
\text { Street performance } \\
201 \text { factors identified }\end{array}$ & $\begin{array}{l}\text { Setting the parameters influencing High Street } \\
\text { performance } \\
\text { Factors influencing High Street change } \\
\text { identified deductively } \\
\text { Collaborating with stakeholders in identifying } \\
\text { additional factors of High Street change } \\
\text { Inductive co-production of theory }\end{array}$ \\
\hline Research design & $\begin{array}{l}\text { Research team } \\
\text { Retail experts } \\
\text { Project partners }\end{array}$ & $\begin{array}{l}\text { Sample selection } \\
\text { Delphi technique } \\
\text { Quantitative/Statistical } \\
\text { analysis } \\
\text { Theoretical model } \\
\text { designed } \\
\text { Top } 25 \text { priorities of } \\
\text { change }\end{array}$ & $\begin{array}{l}\text { Creating a collective learning process by } \\
\text { engaging retail experts in research design } \\
\text { Collaborating with retail experts to finalise the } \\
\text { HSUK2020 model }\end{array}$ \\
\hline Problem-solving & $\begin{array}{l}\text { Research team } \\
\text { Retail experts } \\
\text { Project partners } \\
\text { Communities } \\
\text { High Street } \\
\text { stakeholders }\end{array}$ & $\begin{array}{l}\text { Presenting the } \\
\text { HSUK2020 model } \\
\text { Top } 25 \text { priorities of } \\
\text { change explained } \\
\text { Workshops } \\
\text { Meetings } \\
\text { Reports } \\
\text { Conferences } \\
\text { Radio interviews }\end{array}$ & $\begin{array}{l}\text { Development of forecasting tool based on } \\
\text { footfall data } \\
\text { Engaging a wide range of stakeholders } \\
\text { towards prioritising actions for town centre } \\
\text { change } \\
\text { Disseminating findings to anyone who is } \\
\text { interested in High Street change } \\
\text { internationally }\end{array}$ \\
\hline
\end{tabular}

\section{Table I.}

Summary of project activities and outcomes, based on van de ven's model

\section{Theory building}

Once we had agreed a common knowledge exchange problem, we started further discussions with retail experts, academics and place stakeholders to enhance theory building. At this stage, we wanted to help our project towns to understand their information requirements and get access to accurate and relevant academic knowledge, which could improve the quality of decision-making and provide solid academic underpinning to future plans of action. According to Van de Ven (2007), the knowledge exchange "anomaly" can be resolved by creating a theory/model through processes of abduction, deduction, induction, which can provide a coherent resolution that can also be applicable in subsequent situations. During the stage of problem formulation, we came to the realisation that the fragmentation of the retail literature, and the complexity of factors that impact upon the High Street, leave little room for existing theories to influence change. Therefore, our goal was to develop a model of retail centre change that would stem from a review of the literature and existing theories, as well as from conversations with retail experts that have previously addressed the High Street problem (Van de Ven, 2011). After discussions between the research team 
and our retail experts regarding the future of the High Street, we identified that High Street performance is mainly a reflection of retail performance, with footfall and vacancy rates as key indicators. This "strongly-held assumption" (Van de Ven, 2007, p. 110) served as our initial theory, and given it stemmed from the knowledge and experiences of diverse stakeholders, it appeared to be plausible and worthy of further investigation.

To investigate the factors that would support our theory, we conducted a systematic literature review (see Appendix for search process and review parameters for this study) to form a reliable knowledge base from a range of studies that can be relevant to academics, practitioners and other stakeholders (Tranfield et al., 2003). We initially identified 156 factors that may influence the performance of the High Street. During our first project meeting, and in line with the engaged scholarship model, we presented these initial factors to academic and retail experts, in addition to our town team partners. Participants were asked to comment on the factors and to identify additional performance factors that were not initially ascertained. Partner towns identified 50 additional factors (Parker et al., 2014) that influence the High Street, which led to the review of 33 additional studies. For 12 of those factors that we could find no evidence of their effect on High Street performance, we outlined a research agenda to engage academics on furthering the research on retail change (ibid). Such a scholastic process outlines the foundation of theory building in engaged scholarship, which is based on deductive, literature-based, literature gap formulation and application, and is modified inductively through co-production with practitioners. Moreover, the combination of literature-based and practitioner-based engaged scholarship helped us develop an initial theory and identify 201 factors that can interest researchers and also help practitioners and place stakeholders in their everyday work (Nielsen, 2010). The findings of each stage of the research are presented in the second article in this special issue.

\section{Research design}

At this stage of the research process, we needed to develop the appropriate methods and obtain empirical evidence from our retail experts for evaluating the factors that influence High Street performance (Van de Ven and Johnson, 2006). Given the multitude of interpretations, research philosophies and methods used to measure these factors, a metaanalysis would not be possible. In addition, the extant literature has not conceptualised "performance" (or any other dependent variable) in any comparable manner. Indeed, it is only fairly recently that researchers have been interested in the collaborative activities of stakeholders on the High Street, and we thus knew little about the type of factors these initiatives seek to influence. This subsequently led to two research questions:

\section{$R Q 1$. How much influence does each factor have over High Street performance?}

\section{RQ2. How much influence could the High Street have over the factor?}

Addressing these questions requires an understanding of the dynamic concept of the High Street as a social phenomenon. Therefore, model development needed to take into account not only how much these factors influence High Street performance $(R Q 1)$ but also how people respond and adapt to High Street change over time because of these factors $(R Q 2)$ and under which circumstances or contingencies High Street transformation occurs (Bruner, 1990; Tsoukas, 1989; Van de Ven, 2007). To explore $R Q 1$ and $R Q 2$, we used the Delphi Technique for scoring all factors that may influence the performance of the High Street, as identified from our aforementioned systematic literature review. The Delphi Technique is unique in its method of eliciting and refining group judgement, as it is based on the notion that a group of experts is better than one expert when exact knowledge is not available 
JPMD

10,4

(Paliwoda, 1983). To establish the amount of influence the High Street may have over each identified factor, we first asked 22 retail experts to classify each of the 201 factors as either spatial, macro, meso or micro (Figure 2). Second, we asked respondents to rate how influential each factor was on the vitality and viability of the High Street. A five-point Likert scale was used for rating the influence of each factor on the High Street, with 1 being "not at all influential" and 5 "extremely influential". Participants were also free to write additional comments about each factor. The results of the Delphi exercise, after each factor was plotted, can be seen in Figure 3.

Despite the purpose of a Delphi study being to establish sufficient expert consensus to make a forecast or assignment of values believable or useful (Shields $e t$ al., 1987), this did not limit us from treating it as a collective learning process that would enhance our perspectives on the issues of the High Street (Peluchette and Gerhardt, 2015). Discussions during the Delphi exercise and the experts' comments unveiled that from the long list of 201 factors, many had either the same meaning/definition or were conceptually related. We thus adopted a novel exploratory approach, including statistical tests, to combine those factors which encapsulated the same meaning or were highly related (e.g. "visual appearance" and "cleanliness") (Parker et al., 2016). This resulted in a more coherent representation of factors and scales, based on the advice from retail experts. Moreover, we realised that to bring further clarity, we needed to identify the Top 25 priorities for change based on the results from the "Get on with it!" quadrant (Figure 4). This is because these micro factors can be influenced by High Street stakeholders and can also have the greatest influence on the vitality and viability of High Streets. This decision was mainly informed by the interests and perspectives of the town partnerships involved in the project, which, given their lack of time and resources, were looking for a model that could help them to focus activity and resources on action that will have the most impact on vitality and viability (Parker et al., 2016).

Figure 2.

Level of influence High Streets have over High Street performance factors

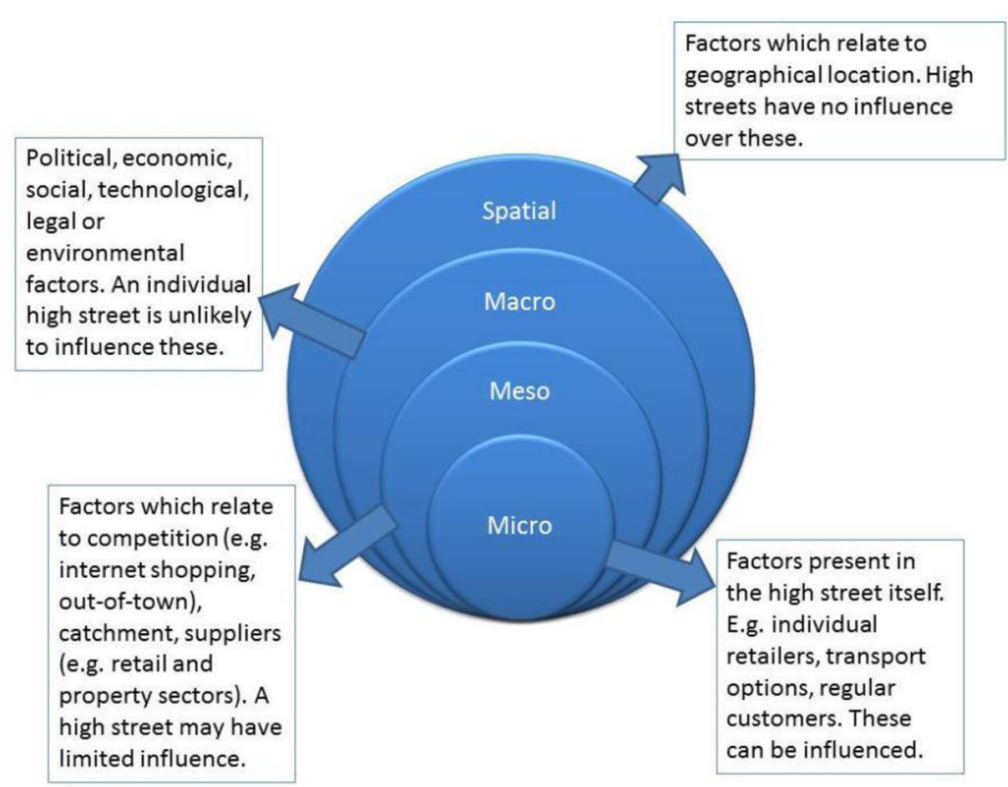



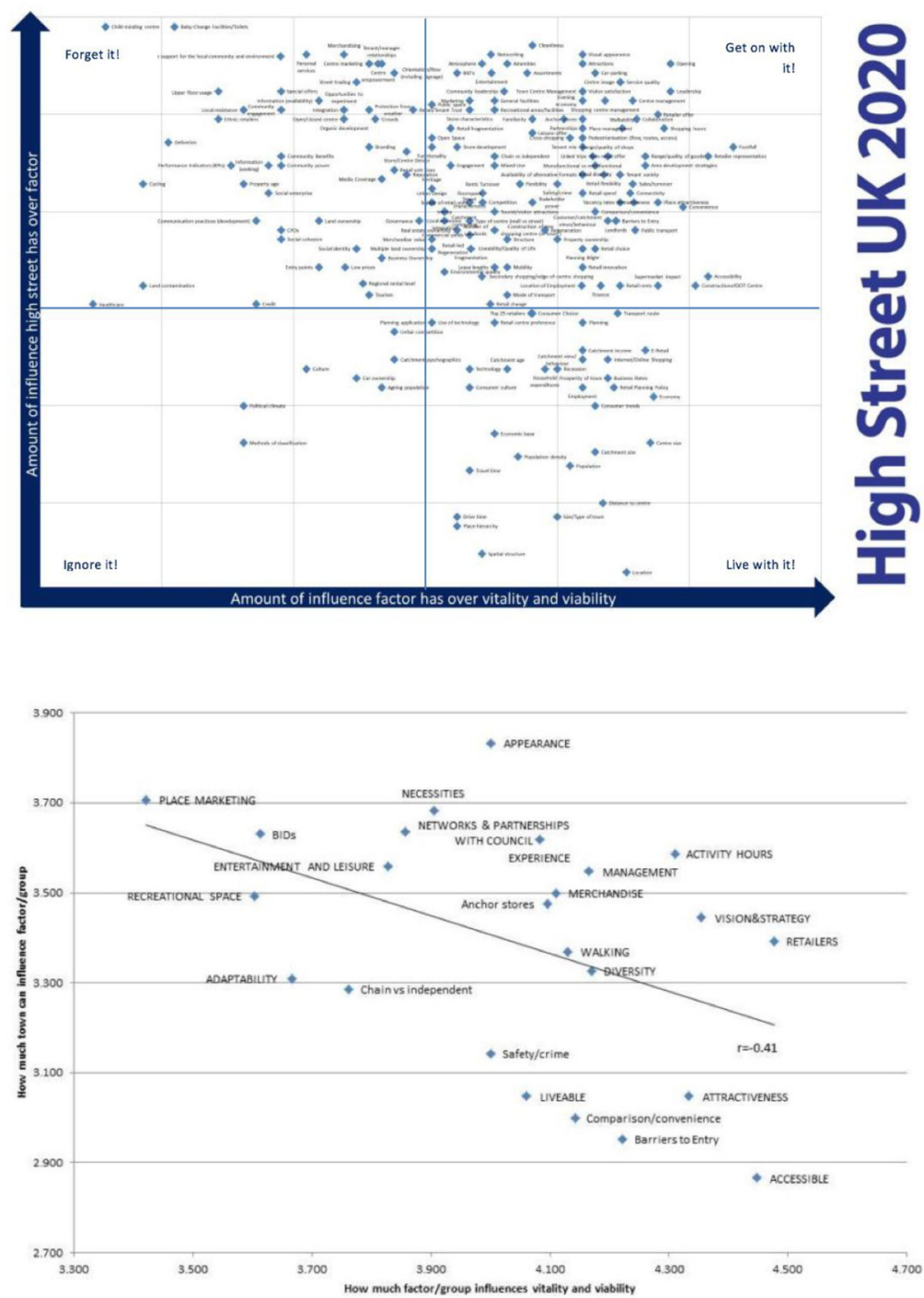

Figure 4.

\section{Problem-solving}

After the completion of the model and the formulation of the top 25 priorities, we embarked on a variety of activities to communicate and apply the HSUK2020 model to our ten towns (Alsager, Altrincham, Ballymena, Barnsley, Bristol (Church Road, St George), Congleton, Holmfirth, Market Rasen, Morley and Wrexham). At the problem-solving stage, which entails the dissemination, interpretation and application of empirical findings (Phillips et al., 2013), the impact of the study is the criterion that outlines the usefulness of research findings (Hunt, 2008). Consequently, we sought to ensure that HSUK2020 will leave a suite of legacy products (e.g. the HSUK2020 modelling tool; podcasts from academic experts; 
JPMD

10,4

intervention place templates; reports; and the special issue of this journal), which can eventually facilitate change in behaviour, conditions and in the way communities interpret co-produced knowledge in their own High Streets (Franz, 2009).

Subsequently, amplifying HSUK2020's impact and legacy involved continued interactions and discussions between the research team, our retail experts and practitioners and our ten towns. Half-day workshops have been run in all ten locations, in which local partners were introduced to the 201 factors and top 25 priorities for change, and offered their own perspectives on how these can inform town centre decision-making. In addition, action planning seminars offered an update on the reflection of our findings, including a new forecasting tool that enabled each centre to consider different scenarios, based on footfall data provided by one of our project partners. Appropriate place interventions, under the broad categories of "repositioning", "reinventing", "rebranding" and "restructuring", were also contextualised in partnership with our ten user communities. These help individual High Streets to identify an alternative, sustainable future for their High Street in 2020, in addition to developing an action plan for achieving that aim.

At this stage, a greater sharing of power and activities (Van de Ven, 2007) between the research team and our town partners allowed us to take advantage of their skills in engaging with the best possible audiences and even in designing some of the research activities. Taking a back seat during workshops and presentations made all activities a collective learning experience and in turn enabled us to concentrate on "problem solving and action, looking for 'what works' not just on participation and communication of new voices and categories" (Strumińska-Kutra, 2016, p. 879). However, during these activities and workshops, we did not hesitate from sometimes challenging the established conventions of town centre management and highlighting the necessity for developing applicable action plans to our project towns, based on the novel contributions and knowledge that our continuing engagement with them produced.

Consequently, a more positive story about town centre change cascaded throughout the project, which in turn encouraged more collaboration across stakeholders, namely, a story of "hope" rather than "doom and gloom". This engaged a number of media (i.e. local press, national radio and local radio), and such coverage of the local workshops and subsequent interviews helped to disseminate the priority actions that had been agreed by the towns, through the HSUK2020 project. Furthermore, the project was acknowledged in Wrigley and Lambiri's (2015) report, "British High Streets: from Crisis to Recovery?", and research findings have been presented to numerous conferences, symposiums and meetings in the UK, Europe, Latin and North America, thus furthering HSUK2020's impact internationally.

\section{Conclusion}

In an era of transformative retail change (Millington et al., 2015), forces such as internet retailing, multichannel/omnichannel retailing, the rise of different convenience cultures and car ownership and its relationship out-of-town developments have already permeated and altered the fabric of our High Streets and town centres. The complex nature of the High Street requires all stakeholders (insiders and outsiders) to work together effectively, to develop the basic knowledge and resources that can explain how we can create sustainable town centres in the near future (Louis and Bartunek, 1992). In this respect, collaborative forms of engaged scholarship, such as the one described in this paper, can "generate knowledge on big questions and issues by testing alternative ideas and different views of a common problem" (Peluchette and Gerhardt, 2015, p. 416). As we demonstrated throughout this paper, the joint knowledge production between the research team and the community enabled us to improve our understanding of the factors affecting High Streets amongst a 
diverse group of stakeholders rather than remotely drawing our own conclusions regarding the factors influencing High Streets (Lewis, 2012).

As successful as our approach was, we are not arguing that engaged scholarship model is the new "golden standard" on how to conduct research in retailing and town centre change (Van de Ven, 2007). Like any approach, engaged scholarship can suffer from the biases and the disparities between the goals and problem-solution cycles of academics, field experts, practitioners and local communities (McKelvey, 2006). However, engaged scholarship can pave the way for beneficial collaboration that can "produce research findings that make more significant advancements to theory and practice than the traditional approach of going it alone" (Van de Ven, 2007, p. 296). The ongoing impact of HSUK2020 on our project towns' action plans, and its success in securing further funding for extending our research on High Street change, are testaments to how engaged scholarship research can drive the agendas for both academics and communities. As scholars, we have benefitted enormously from creating relevant knowledge for our High Streets with the people who work, shop, live and use them every day, who in turn carried the torch of knowledge to their local councils and other networks. This illustrates how engaged scholarship not only can become a valuable tool for researchers but also has the potential to motivate communities to become more involved in the revamping of their centres. Hopefully, as demonstrated in our paper, such a development can make a difference to the vitality and viability of our High Streets.

\section{References}

Albrechts, L. (2015), "Ingredients for a more radical strategic spatial planning", Environment and Planning B: Planning and Design, Vol. 42 No. 3, pp. 510-525.

Alvesson, M. and Sköldberg, K. (2000), Reflexive Methodology: New Vistas for Qualitative Research, Sage, London.

Arkesteijn, M.H. and Volker, L. (2013), “The power of pluralism for urban strategies”, Cities, Vol. 31, pp. 328-336.

Azevedo, J. (1997), Mapping Reality: An Evolutionary Realist Methodology for the Natural and Social Sciences, SUNY Press, Albany, NY.

Balloch, S. and Taylor, M. (2001), Partnership Working: Policy and Practice, Policy Press, Bristol.

Boyer, E.L. (1990), Scholarship Reconsidered: Priorities of the Professorate, Carnegie Foundation, Princeton, NJ.

Boyer, E.L. (1996), "The scholarship of engagement", Bulletin of the American Academy of Arts and Sciences, Vol. 49 No. 7, pp. 18-33.

Brand, R. and Gaffikin, F. (2007), "Collaborative planning in an uncollaborative world", Planning Theory, Vol. 6 No. 3, pp. 282-313.

Bruner, J. (1990), Acts of Meaning, Harvard University Press, Cambridge, MA.

Clarke, I., Bennison, D. and Pal, J. (1997), “Towards a contemporary perspective of retail location", International Journal of Retail \& Distribution Management, Vol. 25 No. 2, pp. 59-69.

Coca-Stefaniak, A. and Carroll, S. (2015), "Traditional or experiential places? Exploring research needs and practitioner challenges in the management of town centres beyond the economic crisis", Journal of Urban Regeneration and Renewal, Vol. 9 No. 1, pp. 38-45.

Coca-Stefaniak, A., Hallsworth, A.G., Parker, C., Bainbridge, S. and Yuste, R. (2005), "Decline in the british small shop independent retail sector: exploring European parallels", Journal of Retailing and Consumer Services, Vol. 12 No. 5, pp. 357-371.

Cuthill, M. (2010), "Working together: a methodological case study of 'engaged scholarship", Gateways: International Journal of Community Research and Engagement, Vol. 3, pp. 20-37. 
JPMD 10,4

Dawkins, G. and Grail, J. (2007), "Business improvement districts: past, present, future", Economic Affairs, Vol. 27 No. 1, pp. 79-82.

DCLG (2009), Transforming Places, Changing Lives: Taking Forward the Regeneration Framework, Communities and Local Government Publications, Communities and Local Government Publications London, London.

Denis, J.-L., Langley, A. and Rouleau, L. (2007), "Strategizing in pluralistic contexts: rethinking theoretical frames”, Human Relations, Vol. 60 No. 1, pp. 179-215.

Depriest-Hricko, L.R. and Prytherch, D.L. (2013), "Planning and sense of place in a 'dying' downtown: articulating memories and visions in Middletown, Ohio”, Journal of Urban Design, Vol. 18 No. 1, pp. 145-165.

De Nisco, A., Riviezzo, A. and Napolitano, M.R. (2008), "The role of stakeholders in town centre management: guidelines for identification and analysis", Journal of Place Management and Development, Vol. 1 No. 2, pp. 166-176.

Franz, N.K. (2009), "A holistic model of engaged scholarship: telling the story across higher education's missions", Journal of Higher Education Outreach \& Engagement, Vol. 13 No. 4, pp. 31-49.

Geddes, M. (2006), "Partnership and the limits to local governance in England: institutionalist analysis and neoliberalism", International Journal of Urban and Regional Research, Vol. 30 No. 1, pp. 76-97.

Gibbons, M., Limoges, C., Nowotny, H., Schwartzman, S., Scott, P. and Trow, M. (1994), The New Production of Knowledge: The Dynamics of Science and Research in Contemporary Societies, Sage, London.

Healey, P. (1998), "Building institutional capacity through collaborative approaches to urban planning", Environment and Planning A, Vol. 30 No. 9, pp. 1531-1546.

Healey, P. (2006), Urban Complexity and Spatial Strategies: Towards a Relational Planning for Our Times, Routledge, London.

Hendrickx, M. (1999), "What can management researchers learn from Donald Campbell, the philosopher? An exercise in hermeneutics", in Baum, J.A.C. and McKelvey, B. (Eds), Variations in Organization Science: In Honor of Donald T. Campbell, Sage, Thousand Oaks, CA, pp. 339-382.

Hernandez, T., Bennison, D. and Cornelius, S. (1998), "The organisational context of retail locational planning", GeoJournal, Vol. 45 No. 4, pp. 299-308.

Hillier, J. (2003), “'Agon’izing over consensus: why Habermasian ideals cannot be 'real”, Planning Theory, Vol. 2 No. 1, pp. 37-59.

Hunt, S.D. (2008), "Book review: Andrew H. van de Ven engaged scholarship: a guide for organizational and social research: 2007 Oxford university press, Oxford”, Organization Studies, Vol. 29 No. 11, pp. 1469-1475.

Huzzard, T. and Johansson, Y. (2014), "Critical action research”, in Jeanes, E. and Huzzard, T. (Eds), Critical Management Research: Reflections from the Field, Sage, London, pp. 81-101.

Innes, J.E. (1996), "Planning through consensus building", Journal of the American Planning Association, Vol. 62 No. 4, p. 460.

King, D. and Learmonth, M. (2015), "Can critical management studies ever be 'practical'? A case study in engaged scholarship", Human Relations, Vol. 68 No. 3, pp. 353-375.

Le Feuvre, M., Medway, D., Warnaby, G., Ward, K. and Goatman, A. (2016), "Understanding stakeholder interactions in urban partnerships", Cities, Vol. 52, pp. 55-65.

Learmonth, M., Lockett, A. and Dowd, K. (2012), "Promoting scholarship that matters: the uselessness of useful research and the usefulness of useless research", British Journal of Management, Vol. 23 No. 1, pp. 35-44.

Lewis, L.K. (2012), "Becoming useful: using engaged scholarship as a means to move NPO scholarship forward", Management Communication Quarterly, Vol. 26 No. 1, pp. 186-192. 
Louis, M.R. and Bartunek, J.M. (1992), "Insider/outsider research teams", Journal of Management Inquiry, Vol. 1 No. 2, pp. 101-110.

McKelvey, B. (2006), "Van de Ven and Johnson's 'engaged scholarship': nice try, but ...., Academy of Management Review, Vol. 31 No. 4, pp. 822-829.

Millington, S., Ntounis, N., Parker, C. and Quin, S. (2015), Multifunctional Centres: A Sustainable Role for Town and City Centres, Institute of Place Management, Manchester.

Morganosky, M.A. (1997), "Retail market structure change: implications for retailers and consumers", International Journal of Retail \& Distribution Management, Vol. 25 No. 8, pp. 269-274.

Mouffe, C. (2005), On the Political, Routledge, London.

Nielsen, R.P. (2010), "Practitioner-based theory building in organizational ethics", Journal of Business Ethics, Vol. 93 No. 3, pp. 401-406.

Omholt, T. (2013), "Developing a collective capacity for place management", Journal of Place Management and Development, Vol. 6 No. 1, pp. 29-42.

Paliwoda, S.J. (1983), "Predicting the future using Delphi”, Management Decision, Vol. 21 No. 1, pp. 31-38.

Parker, C., Ntounis, N., Quin, S. and Grime, I. (2014), "High street research agenda: identifying high street research priorities", Journal of Place Management and Development, Vol. 7 No. 2, pp. 176-184.

Parker, C., Ntounis, N., Quin, S. and Millington, S. (2016), Identifying Factors That Influence Vitality and Viability, Institute of Place Management, Manchester.

Paynter, (2014), "Tackling wicked problems through engaged scholarship", Journal of Community Engagement and Scholarship, Vol. 7 No. 1, pp. 48-60. S.

Peel, D. (2003), “Town Centre management: multi-stakeholder evaluation. Increasing the sensitivity of paradigm choice", Planning Theory \& Practice, Vol. 4 No. 2, pp. 147-164.

Peel, D. (2010), "Making an impact in the built environment?", Journal for Education in the Built Environment, Vol. 5 No. 1, pp. 1-6.

Peluchette, J. and Gerhardt, M.W. (2015), “Andrew H. Van de Ven: reflections on current and future challenges in engaged scholarship", Journal of Leadership \& Organizational Studies, Vol. 22 No. 4, pp. 413-417.

Pettigrew, A.M. (2001), "Management research after modernism", British Journal of Management, Vol. 12 No. s1, pp. S61-S70.

Phillips, J., May, K. and Bailey, J. (2013), "Engaged scholarship model”, in Kessler, E.H. (Ed.), Encyclopedia of Management Theory, Sage, Thousand Oaks, CA, pp. 235-237.

Pioch, E. and Byrom, J. (2004), "Small independent retail firms and locational decision-making: outdoor leisure retailing by the crags", Journal of Small Business and Enterprise Development, Vol. 11 No. 2, pp. 222-232.

Raco, M. (2000), "Assessing community participation in local economic development lessons for the new urban policy", Political Geography, Vol. 19 No. 5, pp. 573-599.

Rescher, M. (2003), Nature and Understanding: The Metaphysics and Method of Science, Oxford University Press, New York, NY.

Shapiro, D.L., Kirkman, B.L. and Courtney, H.G. (2007), "Perceived causes and solutions of the translation problem in management research", The Academy of Management Journal, Vol. 50 No. 2, pp. 249-266.

Shields, T.J., Silcock, G.W.H., Donegan, H.A. and Bell, Y.A. (1987), "Methodological problems associated with the use of the Delphi technique", Fire Technology, Vol. 23 No. 3, pp. 175-185.

Smith, S., Ward, V. and House, A. (2011), "Impact' in the proposals for the UK's research excellence framework: shifting the boundaries of academic autonomy", Research Policy, Vol. 40 No. 10, pp. 1369-1379. 
JPMD

10,4

\section{2}

Starkey, K. and Madan, P. (2001), "Bridging the relevance gap: aligning stakeholders in the future of management research", British Journal of Management, Vol. 12 No. s1, pp. S3-S26.

Strumińska-Kutra, M. (2016), "Engaged scholarship: steering between the risks of paternalism, opportunism, and paralysis", Organization, Vol. 23 No. 6, pp. 864-883.

Taylor, M. (2006), "Communities in partnership: developing a strategic voice", Social Policy and Society, Vol. 5 No. 2, pp. 269-279.

Tranfield, D., Denyer, D. and Smart, P. (2003), "Towards a methodology for developing evidenceinformed management knowledge by means of systematic review", British Journal of Management, Vol. 14 No. 3, pp. 207-222.

Tsoukas, H. (1989), "The validity of idiographic research explanations", The Academy of Management Review, Vol. 14 No. 4, pp. 551-561.

Van de Ven, A.H. (2007), Engaged Scholarship: A Guide for Organizational and Social Research: A Guide for Organizational and Social Research, Oxford University Press, Oxford.

Van de Ven, A.H. (2011), "Building a European community of engaged scholars", European Management Review, Vol. 8 No. 4, pp. 189-195.

Van de Ven, A.H. and Johnson, P.E. (2006), "Knowledge for theory and practice", Academy of Management Review, Vol. 31 No. 4, pp. 802-821.

Wang, E. (2011), "Understanding the 'retail revolution' in urban China: a survey of retail formats in Beijing”, The Service Industries Journal, Vol. 31 No. 2, pp. 169-194.

Warnaby, G., Bennison, D. and Davies, B.J. (2005), "Marketing communications in planned shopping centres: evidence from the UK", International Journal of Retail \& Distribution Management, Vol. 33 No. 12, pp. 893-904.

Wells, P. (2016), "Economies of scale versus small is beautiful: a business model approach based on architecture, principles and components in the beer industry", Organization and Environment, Vol. 29 No. 1, pp. 36-52.

Willmott, H. (2008), “Critical management and global justice”, Organization, Vol. 15 No. 6, pp. 927-931.

Wolfram Cox, J., LeTrent-Jones, T.G., Voronov, M. and Weir, D. (2009), Critical Management Studies at Work: Negotiating Tensions Between Theory and Practice, Edward Elgar, Cheltenham.

Woolrych, R. and Sixsmith, J. (2013), "Placing well-being and participation within processes of urban regeneration", International Journal of Public Sector Management, Vol. 26 No. 3, pp. 216-231.

Wrigley, N. and Dolega, L. (2011), "Resilience, fragility, and adaptation: new evidence on the performance of UK high streets during global economic crisis and its policy implications", Environment and Planning A, Vol. 43 No. 10, pp. 2337-2363.

Wrigley, N. and Lambiri, D. (2014), High Street Performance and Evolution: A Brief Guide to the Evidence, University of Southampton, Southampton.

Wrigley, N. and Lambiri, D. (2015), British High Streets: From Crisis to Recovery? A Comprehensive Review of the Evidence, University of Southampton, Southampton. 


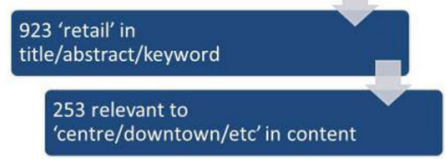

Figure A1.

\section{Review parameters}

(1) Type of study (empirical, exploratory, conceptual)

(2) Methodological evidence

(3) Data source (primary, secondary, tertiary)

(4) Dependent variable (retail area performance measure)

(5) Independent variables (factors affecting performance)

(6) Significance (major findings and statistical significance)

(7) Limitations of study

(8) Author, date, publisher

(9) Geographical location of study (e.g. UK, US, Europe)

(10) Size of retail/shopping centre (different geographical scales of place, e.g. city centre; town centre; High Street; neighbourhood centre; district centre; suburban centre)

\section{Corresponding author}

Nikos Ntounis can be contacted at: n.ntounis@mmu.ac.uk

For instructions on how to order reprints of this article, please visit our website: 